\title{
MENINGKATKAN KEMAMPUAN KOMUNIKASI MATEMATIS SISWA KELAS V SD NEGERI 064997 KECAMATAN MEDAN LABUHAN MELALUI PENDEKATAN MATEMATIKA REALISTIK
}

\author{
Ika Okta Kirana \\ Dosen STIKOM Tunas Bangsa Pematangsiantar, Sumatera Utara-Indonesia \\ Jalan Sudirman Blok A No. 1, 2, 3 Pematangsiantar \\ ikaoktakirana1989@gmail.com
}

\begin{abstract}
This study aims to: (1) Improve students 'mathematical communication skills, and (2) Know the effectiveness of applying realistic mathematics learning to students' mathematics learning. This study is a classroom action research conducted in class V SD Negeri 064997 with the number of students as much as 19 people. Instruments used to collect data consist of tests, student and teacher activity observation sheets, and student response questionnaires. The result of the research shows: (1) realistic mathematics learning can improve students' mathematical communication ability, for class classification increased from $68,71 \%$ in cycle I to $72,96 \%$ in cycle II and $80,99 \%$ in cycle III, (2) realistic mathematics learning to the effective learning process mathematics, marked by the achievement of (i) classical mastery of 88.89\% above the set criteria that is $85 \%$, (ii) completeness of learning objectives in the third cycle reached $88.88 \%$ of students who achieve complete learning objectives $75 \%$ for each individual, (iii) the percentage of good category student activity is $77,78 \%$ at first meeting and second meeting $83,33 \%$ in cycle III, for teacher ability to manage learning equal to $82,05 \% \%$, (iv) time efficient, where the application of learning has been carried out in accordance with the time in RPP (v) student response to realistic mathematics learning dika very good categorization, to score the student's response questionnaire of $81.25 \%$ in cycle III.
\end{abstract}

Keywords: ability, mathematical communication, learning, mathematics, realistic

\begin{abstract}
Abstrak
Penelitian ini bertujuan untuk: (1) Meningkatkan kemampuan komunikasi matematis siswa, dan (2) Mengetahui efektivitas penerapan pembelajaran matematika realistik terhadap pembelajaran matematika siswa. Penelitian ini merupakan penelitian tindakan kelas yang dilakukan di kelas V SD Negeri 064997 dengan jumlah siswa sebanyak 19 orang. Instrumen yang digunakan untuk mengumpulkan data terdiri dari tes, lembar observasi aktivitas siswa dan guru, dan angket respon siswa. Hasil penelitian menunjukkan: (1) pembelajaran matematika realistic dapat meningkatkan kemampuan komunikasi matematis siswa, untuk klasikal kelas meningkat dari 68,71\% pada siklus I menjadi $72,96 \%$ pada siklus II serta 80,99\% pada siklus III, (2) penerapan pembelajaran matematika realistik terhadap proses pembelajaran matematika efektif, ditandai dengan tercapainya (i) ketuntasan klasikal sebesar 88,89\% diatas kriteria yang ditetapkan yaitu 85\%,(ii) ketuntasan tujuan pembelajaran pada siklus III mencapai $88,88 \%$ siswa yang mencapai ketuntasan tujuan pembelajaran $75 \%$ untuk setiap individu, (iii) persentase aktivitas siswa kategori baik sebesar 77,78\% pada pertemuan pertama dan pertemuan kedua sebesar $83,33 \%$ pada siklus III, untuk kemampuan guru mengelola pembelajaran sebesar 82,05\% diatas kriteria yang ditetapkan yaitu 80\%, (iv) waktu yang efisien, dimana penerapan pembelajaran telah
\end{abstract}


dilaksanakan sesuai dengan waktu pada RPP (v) respon siswa terhadap pembelajaran matematika realistik dikategorikan sangat baik, untuk skor angket respon siswa sebesar 81,25\% pada siklus III.

Kata kunci: kemampuan, komunikasi matematis, pembelajaran, matematika, realistic

\section{PENDAHULUAN}

Pembelajaran matematika yang optimal seharusnya dapat membuat siswa menjadi pandai menyelesaikan permasalahan dimana tujuan ini dapat tercapai bila prinsip pembelajaran matematika diterapkan secara dua arah sehingga siswa dapat benar-benar menguasai konsep-konsep matematika dengan baik. Selain itu, siswa diharapkan pandai dalam berhitung dan mampu melakukan perhitungan dengan benar dan tepat sesuai kreativitas diri siswa masing-masing. Pada dasarnya belajar matematika haruslah dimulai dari mengerjakan masalah yang berkaitan dengan kehidupan sehari-hari. Melalui mengerjakan masalah yang dikenal dan berlangsung dalam kehidupan nyata, peserta didik dapat membangun konsep dan pemahaman dengan naluri, insting, daya nalar, dan konsep yang telah diketahui. Pembelajaran harus dapat membantu siswa mengkomunikasikan ide matematik melalui lima aspek komunikasi yaitu representing, listening, reading, discussing and writing.

Kemampuan komunikasi matematis dapat diartikan sebagai suatu kemampuan siswa dalam menyampaikan sesuatu yang diketahuinya. [1] mengatakan bahwa komunikasi matematik merupakan: (1) kekuatan sentral bagi siswa dalammerumuskan konsep dan strategi matematik, (2) modal keberhasilan bagi siswa terhadap pendekatan dan penyelesaian dalam eksplorasi dan investigasi matematik, (3) wadah bagi siswa dalam berkomunikasi dengan temannya untuk memperoleh informasi, membagi pikiran dan penemuan, curah pendapat, menilai dan mempertajam ide untuk meyakinkan orang lain. Komunikasi matematik perlu menjadi fokus perhatian dalam pembelajaranmatematika, sebab melalui komunikasi, siswa dapat mengorganisasi dan mengkonsolidasi berpikir matematisnya, dan siswa dapat meng'explore' ideide matematika [2].

Masalah belajar diatas dapat terlihat ketika guru memberikan ulangan harian kebanyakan siswa kelas V SD Negeri 064997 Kecamatan Medan Labuhan salah dalam menyelesaikan suatu permasalahan. Akibatnya dari 19 siswa sebanyak 14 siswa atau $73,68 \%$ belum tuntas belajar dan rata-rata nilai ulangan harian kurang dari batas ketuntasan belajar minimal yaitu 65, serta siswa tidak paham dalam memecahkan masalah yang terdapat pada soal. Dalam proses pembelajaran, respon siswa terhadap pembelajaran juga menjadi sesuatu yang sangat penting untuk diperhatikan. Hal ini disebabkan karena pembelajaran adalah proses interaksi yang dilakukan oleh guru dan siswa di dalam maupun di luar kelas dengan menggunakan berbagai sumber belajar sebagai bahan kajian. Interaksi antara guru dan siswa akan efektif jika berlangsung dua arah. Guru diharapkan menciptakan proses pembelajaran yang dapat memunculkan respons siswa. Respons siswa dapat dilihat dari partisipasi siswa selama proses pembelajaran. 


\section{METODOLOGI PENELITIAN}

\subsection{Kemampuan Komunikasi Matematis}

Ada 2 alasan penting yang menjadikan komunikasi dalam pembelajaran matematika perlu menjadi fokus perhatianyaitu (1) mathematics as language (matematika sebagai bahasa); matematika tidak hanya sekedar alat bantuberpikir (a tool to aid thinking), alat untuk menemukan pola, atau menyelesaikan masalah namun matematika juga "an invaluable tool for communicating a variety of ideas clearly, precisely, and succintly," dan (2) mathematics learning as social activity (belajar matematika merupakan aktivitas sosial); sebagai aktivitas sosial, dalam pembelajaran matematika, interaksi antarsiswa, seperti juga komunikasi guru siswa merupakan bagian penting untuk "nurturing children's mathematical potential" [3].

Sejumlah pakar telah mendefenisikan pengertian, prinsip, dan standar komunikasi matematis. [2] Mengemukakan bahwa standar kurikulum, matematika sebagai alat komunikasi (mathematics as communication) untuk siswa kelas 5 - 8 (SMP) adalah dapat: (1) memodelkan situasi baik secara lisan, tulisan, nyata, gambar, graphis, dan metode aljabar; (2) merefleksikan dan mengklarifikasikan pemikiran mereka sendiri tentang ide-ide matematika dan hubungannya; (3) mengembangkan pemahaman dengan ide-ide matematika kedalam aturan dan defenisi; (4) menggunakan kemampuan membaca, mendengar untuk menginterpretasikan dan mengevaluasi ide-ide matematika; (5)mendiskusikan ide-ide matematika, membuat konjektur dan meyakinkan argumen; (6) mengapresiasikan nilai, notasi matematika, dan perannya dalam mengembangkan ide-ide matematika.

Kemampuan komunikasi matematis dalam penelitian ini diukur melalui indikator-indikator berikut ini: (1) menyatakan masalah kehidupan sehari-hari kedalam symbol atau bahasa matematis, (2) menginterpretasikan gambar ke dalam model matematika, (3) menuliskan informasi dari pernyataan ke dalam bahasa matematika.

\subsection{Efektivitas Pembelajaran Matematika}

Kriteria utama suatu proses pembelajaran dapat dikatakan berhasil adalah dengan tercapainya tujuan yang telah ditetapkan sebelumnya. Proses untuk mencapai tujuan tersebut harus memperhatikan beberapa faktor, salah satunya adalah efektivitas dalam pembelajaran. Menurut [4] Efektivitas berkaitan dengan terlaksananya semua tugas pokok, tercapainya tujuan, ketepatan waktu, adanya partisipasi aktif dari anggota. Pembelajaran dikatakan efektif apabila dalam proses pembelajaran setiap elemen berfungsi secara keseluruhan, peserta merasa senang, puas dengan hasil pembelajaran, membawa kesan, sarana/fasilitas memadai, materi dan metode affordable, guru profesional. Keefektifan program pembelajaran tidak hanya ditinjau dari segi tingkat prestasi belajar, melainkan ditinjau dari segi proses dan sarana penunjang..

Menurut [5] kriteria keefektifan mengacu pada (1)ketuntasan belajar, pembelajaran dapat dikatakan tuntas apabila sekurang-kurangnya $75 \%$ dari jumlah siswa telah memperoleh nilai $=65$ dalam peningkatan prestasi belajar. (2) Model pembelajaran dikatakan efektif meningkatkan hasil belajar siswa apabila 
hasil belajar siswa menunjukkan perbedaan yang signifikan antara pemahaman awal dengan pemahaman setelah pembelajaran (gain yang signifikan). (3) Model pembelajaran dikatakan efektif jika dapat meningkatkan minat dan motivasi apabila setelah pembelajaran siswa menjadi lebih termotivasi untuk belajar lebih giat dan memperoleh hasil belajar yang lebih baik.

Sedangkan menurut [6] pembelajaran dikatakan efektif apabila mencapai indikator kefektifan pembelajaran berupa: (1) Ketercapaian keefektifan aktivitas siswa, yaitu pencapaian waktu ideal yang digunakan siswa untuk melakukan setiap kegiatan dalam rencana pembelajaran. (2) Ketercapaian kemampuan guru mengelola pembelajaran. (3) Respon siswa terhadap pembelajaran positif. (4) Ketercapaian ketuntasan belajar.

\subsection{Pendekatan Matematika Realistik}

Pendekatan matematika realistik adalah sebuah pendekatan belajar matematika yang dikembangkan sejak tahun 1971 oleh sekelompok ahli matematika dari Freudenthal Institute, Utrecht University di Negeri Belanda. Pendekatan ini didasarkan pada anggapan [3] bahwa matematika adalah kegiatan manusia. Menurut pendekatan ini, kelas matematika bukan tempat memindahkan matematika dari guru kepada siswa, melainkan tempat siswa menemukan kembali ide dan konsep matematika melalui eksplorasi masalah-masalah nyata.

Karakteristik PMR adalah menggunakan konteks 'dunia nyata', model-model, produksi dan konstruksi siswa, interaktif dan keterkaitan (intertwinment)[7]. (1) Menggunakan konteks 'dunia nyata',pembelajaran diawali dengan masalah konstekstual ('dunia nyata'), sehingga memungkinkan mereka menggunakan pengalaman sebelumnya secara langsung, (2) Menggunakan model-model (matematisasi), istilah model berkaitan dengan model situasi dan model matematik yang dikembangkan oleh siswa sendiri (self developed models) sebagai jembatan bagi siswa dari situasi real ke situasi abstrak atau dari matematika informal ke matematika formal, (3) Menggunakan produksi dan konstruksi, siswa terdorong untuk melakukan refleksi pada bagian yang mereka anggap penting dalam proses belajar, (4) Menggunakan Interaktif, secara eksplisit bentuk-bentuk interaksi dapat berupa negosiasi, penjelasan, pembenaran, setuju, tidak setuju, pertanyaan atau refleksi, dan (5) Menggunakan Keterkaitan (intertwinment), dalam PMR pengintegrasian unit-unit matematika adalah esensial jika dalam pembelajaran kita mengabaikan keterkaitan dengan bidang yang lain, maka akan berpengaruh pada pemecahan masalah.

Menurut [8] implementasi pembelajaran matematika realistik di kelas meliputi tiga fase, yaitu: 1) Fase pengenalan, guru memperkenalkan masalah realistik kepada seluruh siswa serta membantu untuk memberi pemahaman masalah. 2) Fase Eksplorasiswa, pada fase ini siswa mencoba membuat model situasi masalah, berbagi pengalaman/ ide, serta membuat dugaan. 3) Fase Meringkas, peranan siswa pada fase ini adalah mengajukan dugaan, mengajukan pertanyaan kepada siswa yang lain, bernegosiasi, mengajukan alternatif-alternatif pemecahan masalah, memberikan alasan, memperbaiki strategi dan dugaan mereka, serta membuat keterkaitan. Sebagai hasil diskusi siswa diharapkan 
menemukan konsep awal atau pengetahuan matematika formal sesuai dengan tujuan materi.

\subsection{Metode Penelitian}

Jenis penelitian ini adalah tindakan kelas (Classroom Action Research) yaitu suatu bentuk penelitian yang dilakukan guru untuk memperbaiki proses pembelajaran. Dalam hal ini peneliti melakukan kolaboratif dengan guru kelas $\mathrm{V}$ SD Negeri 064997 Kecamatan Medan Labuhan untuk melakukan kegiatan penelitian tindakan pada pembelajaran Matematika di sekolah. Subyek dalam penelitian ini adalah siswa kelas V SD Negeri 064997 Kecamatan Medan Labuhan Tahun Ajaran 2014/ 2015 yang berjumlah 19 orang siswa. Instrumen yang digunakan dalam penelitian ini adalah tes siklus yang dilakukan sebanyak 3 kali, angket respon siswa, serta lembar observasi aktivitas siswa dan guru.

\section{HASIL DAN PEMBAHASAN}

Penelitian tindakan ini merupakan upaya untuk menjawab pertanyaan dalam rumusan masalah penelitian yaitu: 1)Bagaimana peningkatan kemampuan komunikasi matematis siswa, 2)Bagaimana efektivitas penerapan Pembelajaran Matematika Realistik terhadap pembelajaran matematika siswa kelas V SD Negeri 064997 Kecamatan Medan Labuhan tahun pelajaran 2014/2015. Upaya peningkatan tersebut dilakukan melalui penerapan pembelajaran matematika realistik sebagai salah satu alternatif pembelajaran yang inovatif.

Berdasarkan analisis data hasil penelitian yang diperoleh dalam penelitian tindakan ini, maka untuk menjawab ketiga rumusan pertanyaan di atas dilakukan pembahasan berikut.

\subsection{Peningkatan Kemampuan Komunikasi Matematis Siswa Melalui Pembelajaran Matematika Realistik}

Berdasarkan analisis data hasil tes siklus, kemampuan komunikasi matematis siswa menunjukkan peningkatan pada setiap siklusnya.Adapun gambaran peningkatan kemampuan komunikasi matematis dari siklus I sampai dengan siklus III disajikan pada gambar 1 berikut.

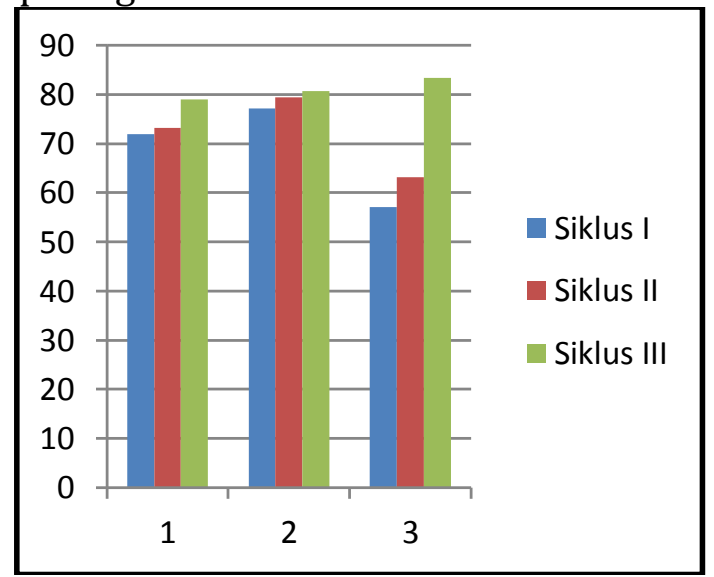

Gambar 1. Grafik Perolehan Skor Kemampuan Komunikasi Matematis Siswa Per Siklus 
Keterangan:

1. Menyatakan masalah kehidupan sehari-hari kedalam symbol/ bahasa matematis

2. Menginterpretasikan gambar kedalam model matematika

3. Menuliskan informasi dari pernyataan kedalam bahasa matematika

Berdasarkan uraian di atas, perolehan hasil tes kemampuan komunikasi matematis siswa dari siklus I ke siklus III mengalami peningkatan secara klasikal. Rata-rata pencapaian indikator kemampuan pemecahan masalah dari siklus I ke siklus II meningkat sebesar 4,25 poin dari $68,71 \%$ menjadi $72,96 \%$. Pencapaian indikator kemampuan pemecahan masalah dari siklus II ke siklus III juga mengalami peningkatan sebesar 8,03 poin yaitu dari $72,96 \%$ menjadi $80,99 \%$. Dengan demikian, kemampuan komunikasi matematis siswa pada siklus III sudah tuntas karena ketuntasan klasikal telah melewati kriteria yang ditetapkan yaitu 80\% dan tindakan dihentikan. Hasil penelitian ini sejalan dengan Pugalee (2001) menyatakan bahwa agar siswa bisa terlatih kemampuan komunikasi matematisnya, maka dalam pembelajaran siswa perlu dibiasakan untuk memberi argumen atas setiap jawabannya serta memberikan tanggapan atas jawaban yang diberikan oleh orang lain sehingga apa yang sedang dipelajari menjadi lebih bermakna dan membuat komunikasi matematis siswa meningkat.

\subsection{Efektivitas Penerapan Pembelajaran Matematika Realistik Terhadap Pembelajaran Matematika}

Berdasarkan analisis data hasil tes siklus, observasi kegiatan siswa dan guru, serta angket respon siswa dari siklus I sampai dengan siklus III diperoleh adanya peningkatan pada tiap indikator efektivitas.Adapun gambaran keefektivitasan pembelajaran matematika realistik yang dilihat dari adanya peningkatan tiap indikator efektivitas seperti ketuntasan belajar secara klasikal, ketuntasan tujuan pembelajaran, aktivitas siswa dan guru, dan respon siswa dari siklus I sampai dengan siklus III disajikan pada gambar 2 berikut.

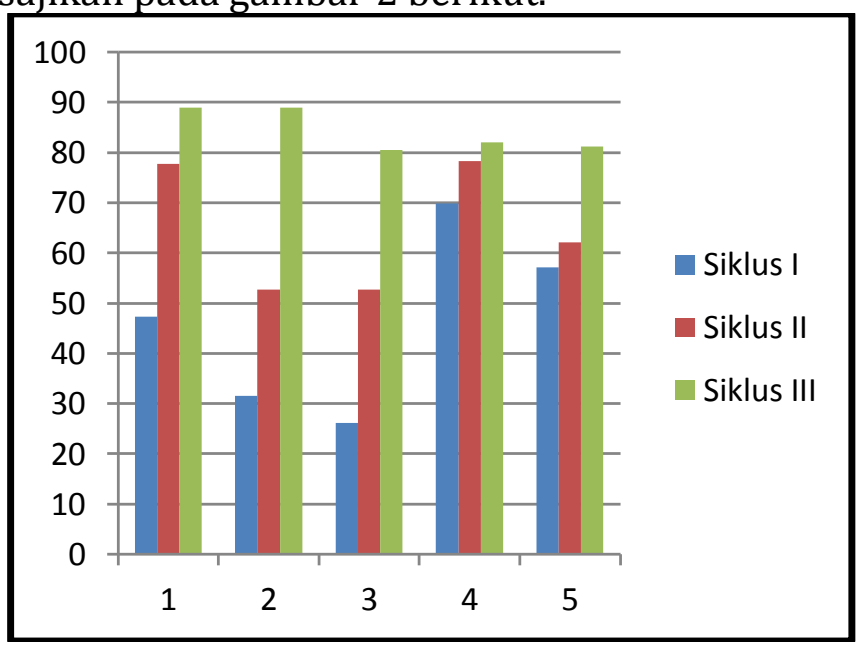

Gambar 2. Peningkatan perolehan skor tiap indikator efektivitas pembelajaran per siklus

Keterangan:

$\begin{array}{ll}1 & \text { : Ketuntasan belajar secara klasikal } \\ 2 & \text { : Ketuntasan tujuan pembelajaran }\end{array}$ 


$\begin{array}{ll}3 & \text { : Aktivitas Siswa } \\ 4 & \text { : Aktivitas guru } \\ 5 & \text { : Respon siswa }\end{array}$

Berdasarkan gambar 4 diatas dapat dilihat data sebagai berikut: dari siklus I sampai dengan siklus III diperoleh ketuntasan belajar secara klasikal siswa mengalami peningkatan. Pada siklus I ketuntasan belajar secara klasikal hanya mencapai $47,37 \%$, lalu pada siklus II meningkat menjadi $77,78 \%$ begitu pula pada siklus III menjadi $88,89 \%$. Pencapaian skor pada siklus III sudah memenuhi kriteria ketuntasan yang ditetapkan pada babIII yaitu $85 \%$. Sedangkan, ketuntasan tujuan pembelajaran dikelas yang diperoleh berdasarkan analisis data hasil latihan siswa yang dilakukan tiap pertemuan mengalami peningkatan setiap siklusnya. Pada siklus I dipertemuan pertama hasil perolehan persentase ketuntasan tujuan pembelajaran siswa adalah $27,78 \%$ atau 5 dari 18 siswa yang memperoleh ketuntasan tujuan pembelajaran sebesar $75 \%$ dan pada pertemuan kedua diperoleh persentase ketuntasan tujuan pembelajaran sebesar 35,29\% atau 6 dari 17 siswa yang memperoleh ketuntasan tujuan pembelajaran sebesar 75\%. Sehingga pada siklus I diperoleh rata-rata ketuntasan tujuan pembelajaran siswa sebesar 31,53\%.Pada siklus II dipertemuan pertama hasil perolehan persentase ketuntasan tujuan pembelajaran siswa adalah $44,44 \%$ atau 8 dari 18 siswa yang memperoleh ketuntasan tujuan pembelajaran sebesar $75 \%$ dan pada pertemuan kedua diperoleh persentase ketuntasan tujuan pembelajaran sebesar $61,11 \%$ atau 11 dari 18 siswa yang memperoleh ketuntasan tujuan pembelajaran sebesar 75\%. Sehingga pada siklus II diperoleh rata-rata ketuntasan tujuan pembelajaran siswa sebesar 52,77\%.Dan pada siklus III dipertemuan pertama hasil perolehan persentase ketuntasan tujuan pembelajaran siswa adalah 83,33\% atau 15 dari 18 siswa yang memperoleh ketuntasan tujuan pembelajaran sebesar 75\% dan pada pertemuan kedua diperoleh persentase ketuntasan tujuan pembelajaran sebesar $94,44 \%$ atau 17 dari 18 siswa yang memperoleh ketuntasan tujuan pembelajaran sebesar $75 \%$. Sehingga pada siklus III diperoleh rata-rata ketuntasan tujuan pembelajaran siswa sebesar $88,88 \%$.

Sama halnya dengan perolehan skor ketuntasan secara klasikal, perolehan skor aktivitas siswa yang mendapatkan kategori baik juga meningkat tiap siklusnya. Pada siklus I terdapat $11,11 \%$ siswa yang memperoleh kategori baik pada pertemuan pertama dan $41,18 \%$ pada pertemuan kedua, sehingga rata-rata perolehan skor aktivitas siswa pada siklus I adalah 26,15\%. Pada siklus II mengalami peningkatan dimana terdapat $44,44 \%$ siswa yang memperoleh kategori baik pada pertemuan pertama dan $61,11 \%$ pada pertemuan kedua, sehingga rata-rata perolehan skor aktivitas siswa pada siklus II adalah 52,77\%. Begitu pula pada siklus III meningkat lagi menjadi $77,78 \%$ siswa yang memperoleh kategori baik pada pertemuan pertama dan $83,33 \%$ pada pertemuan kedua, sehingga rata-rata perolehan skor aktivitas siswa pada siklus III adalah $80,55 \%$.

Kemampuan guru mengelola pembelajaran juga mengalami peningkatan, dimana perolehan skor rata-rata aktivitas guru siklus I terdapat $68,63 \%$ pada pertemuan pertama dan $71,13 \%$ pada pertemuan kedua, sehingga rata-rata perolehan skor aktivitas guru pada siklus I adalah 69,88\%. Pada siklus II 
mengalami peningkatan dimanaperolehan skor rata-rata aktivitas guru terdapat $77,13 \%$ pada pertemuan pertama dan $79,50 \%$ pada pertemuan kedua, sehingga rata-rata perolehan skor aktivitas guru pada siklus II adalah 78,31\%. Begitu pula pada siklus III meningkat lagi menjadi $80,75 \%$ pada pertemuan pertama dan $83,38 \%$ pada pertemuan kedua, sehingga rata-rata perolehan skor aktivitas guru pada siklus III adalah $82,05 \%$.

Sedangkan efisiensi pengelolaan waktu selama proses pembelajaran berlangsung telah peneliti paparkan di awal hasil penelitian tindakan setiap siklusnya, dimana pada siklus III waktu yang digunakan oleh guru dalam penerapan pembelajaran ini sudah sesuai dengan alokasi waktu yang telah direncanakan pada RPP. Namun, di setiap akhir pertemuan masing-masing siklus siswa diberikan waktu tambahan selama 10 menit. Penambahan waktu ini dilakukan atas persetujuan guru kelas dan kesepakatan dengan observer. Hal ini mengingat bahwa siswa harus mengisi angket respon siswa terhadap pembelajaran untuk setiap akhir siklus. Respon siswa terhadap pembelajaran juga menunjukkan peningkatan sebesar 5,07 poin yaitu dari $57,08 \%$ pada siklus I menjadi $62,15 \%$ pada siklus II. Kemudian meningkat lagi sebesar 19,1 poin yaitu dari $62,15 \%$ pada siklus II menjadi $81,25 \%$ pada siklus III.

\section{SIMPULAN}

Berdasarkan hasil analisis data penelitian, dikemukakan beberapa kesimpulan berikut.

1. Kemampuan komunikasi matematis siswa mengalami peningkatan sebesar $4,25 \%$ dari siklus I ke siklus II, dimana kemampuan komunikasi matematis siswa pada siklus I sebesar $68,71 \%$ dan pada siklus II meningkat menjadi $72,96 \%$. Sedangkan kemampuan komunikasi matematis siswa dari siklus II ke siklus III mengalami peningkatan sebesar 8,03\%, dimana kemampuan komunikasi matematis siswa pada siklus II adalah $72,96 \%$ dan meningkat menjadi $80,99 \%$ pada siklus III.Sehingga pembelajaran matematika realistikdapat meningkatkan kemampuan komunikasi matematis siswa kelas $\mathrm{V}$ SD Negeri 064997Kecamatan Medan Labuhan pada materi Pecahan.

2. Penerapan pembelajaran matematika realistik efektif terhadap pembelajaran matematika siswa kelas V SD Negeri 064997 Kecamatan Medan Labuhan pada materi Pecahan. Pembelajaran matematika realistik ini dikatakan efektif karena ketuntasan belajar secara klasikal mencapai 85\%, ketuntasan tujuan pembelajaran mencapai $75 \%$ tiap individu, $80 \%$ siswa memperoleh aktivitas dengan kategori baik dan rata-rata skor kemampuan guru mengelola pembelajaran mencapai $80 \%$. Dalam hal ini, pada siklus I terdapat $26,13 \%$ siswa memperoleh kategori aktivitas baik. Perolehan skor ini meningkat pada siklus II menjadi 52,77\% siswa memperoleh kategori aktivitas baik, begitu pula pada siklus III meningkat menjadi $80,55 \%$. Sedangkan kemampuan guru mengelola pembelajaran pada siklus I adalah $69,88 \%$ dan pada siklus II menjadi 78,31\% lalu pada siklus III meningkat menjadi 82,06\%. Waktu yang digunakan oleh guru sesuai dengan rancangan yang telah dibuat sebelumnya pada RPP.Respon siswa terhadap pembelajaran matematika realistik menunjukkan respon yang positif. Dimana terjadi peningkatan persantase 
respon siswa, pada siklus I diperoleh persentase sebesar 57,08\% dengan kategori respon siswa adalah cukup. Perolehan tersebut meningkat pada siklus II yaitu 62,15\% dengan kategori respon siswa adalah cukup lalu pada siklus III meningkat menjadi $81,25 \%$ dengan kategori respon siswa adalah baik.

\section{DAFTAR PUSTAKA}

[1] Greenes, C. \& Schulman, L. (1996). "Communication Processes in Mathematical Explorations and Investigations". In P. C. Elliott and M. J. Kenney (Eds.). 1996 Yearbook. Communication in Mathematics. K-12 and Be.vond. USA: NCTM.

[2] NCTM (2000). Principles and Standards for School Mathematics, Reston, Virginia.

[3] Freudenthal, H. (1973). Mathematics as an educational task. Dordrecht: Reidel Publishing Company

[4] Hartutik. 2006. Efektivitas Pembelajaran Biologi SMA dengan Pendekatan Jelajah Alam Sekitar (JAS) berdasar Analisis SWOT dalam kemasaan CD interaktif. Tesis: Program Pascasarjana Prodi Pendidikan IPA UNNES.

[5] Nurgana. 1985. Efektivitas Pembelajaran. Bandung: Universitas Pendidikan Indonesia.

http://agungprudent.wordpress.com/2009/06/18/efektivitaspembelajaran/ L Diakses: 25 Agustus 2014 pukul 15.17

[6] Sinambela. 2008. Faktor-faktor penentu keefektifan pembelajaran dalam model pembelajaran berdasar masalah. Jurnal generasi kampus, 1(2): 74-85. http://isjd.pdii.lipi.go.id/admin /jurnal/12087485.pdf// Diakses: 29 mei 2014.

[7] Polya,George. 1988. How to Solve It: A New Aspect of Mathematical Method (Second ed.). Princeton, N.J.: Princeton Science Library Printing.

[8] Sudharta, IGP. 2004. Realistic Mathematics: Apa dan Bagaimana? http://www.depdiknas.co.id/editorial/jurnalpendidikanindonesia// Diakses: 30 Mei 2014 